SAJM

2,2

Received 25 June 2021 Revised 30 September 2021 Accepted 5 October 2021

\section{Emergence of children as influencers in family consumption decisions - a resource theory approach}

\author{
Harikishni Nain \\ Commerce, Bharati College, University of Delhi, Delhi, India
}

\begin{abstract}
Purpose - This paper aims to examine the perception of parents regarding the role of children as influencers in family consumption decisions in India. The purpose is to support marketing practitioners in understanding the stages of children's influence in the family using the theoretical perspective of the resource theory approach. Design/methodology/approach - This study is based on a Web survey approach. Primary data were obtained from a sample of 180 mothers of adolescent children in the age group of 13-18 years and residing in rural and urban areas of Delhi (India) by administering a bilingual (Hindi/English) pre-tested "structured non-disguised" questionnaire designed on the Google Forms.

Findings - The findings that emerged from this study and as supported by the relative theory approach revealed that Indian parents perceive their children to exert a significant influence in family buying decisions, children's influence varies across stages of the decision-making process and the type of product and children's influence in family buying decisions is moderated by family structure but not by family size. The results of this study extend interesting and practical implications for marketing practitioners in India and by extension in other similar countries while designing and implementing marketing mix strategies in respect of goods and services meant for children/family consumption.
\end{abstract}

Research limitations/implications - The findings that emerged from this study and as supported by the relative theory approach revealed that Indian parents perceive their children to exert significant influence in family buying decisions, children's influence varies across stages of the decision-making process and the type of product, and children's influence in family buying decisions is moderated by family structure but not by family size. Results of this study extend interesting and practical implications for marketing practitioners in India and by extension in other similar countries while designing and implementing marketing mix strategies in respect of goods and services meant for children/family consumption.

Practical implications - The results of this study support the notion that children exert considerable influence in family buying decisions in India across products, hence constitute a viable target market for different products consumed not only by them but by other family members as well. It is, therefore, vital that marketers wishing to penetrate family and/or child product markets must identify the person in the family who is likely to be more involved in the buying process and the extent of his involvement to carve effective promotional strategies.

Social implications - The finding that although Indian children are actively participating across various stages of the decision-making process and their influence is strongest at the purchase initiation stage has peculiar social implications whereby families may be exposed toward eco-friendly green products and sustainable ways of living through the children in rural as well as urban areas. Similarly, children were also found to be influential at the information search and evaluation stage; hence, the messages regarding social issues, gender equality and health issues, which are not yet openly discussed in Indian families, may be imparted through children for better coverage and effectiveness.

Originality/value - Children are an important part of the family; especially in the nuclear families, children are an apple of eye and central point of the discussion. The role of children in decision-making is also important

(c) Harikishni Nain. Published in South Asian Journal of Marketing. Published by Emerald Publishing Limited. This article is published under the Creative Commons Attribution (CC BY 4.0) licence. Anyone may reproduce, distribute, translate and create derivative works of this article (for both commercial and non-commercial purposes), subject to full attribution to the original publication and authors. The full terms of this licence may be seen at http://creativecommons.org/licences/by/4.0/legalcode

Data availability statement: It can be made available on request.

Funding statement: This study is self-financed.
South Asian Journal of Marketing Vol. 2 No. 2, 2021 pp. $130-147$

Emerald Publishing Limited e-ISSN: 2738-2486 p-ISSN: $2719-2377$ DOI 10.1108/SAJM-06-2021-0080 
because of the changing information system and modernization of the younger generation. This is an empirical study focusing on the areas not yet explored and examined in the context of a culturally distinct and emerging country in terms of the emergence of children as influencers in family consumption decisions in rural and urban Indian families.

Keywords Family, Web-based survey, Decision-making stages, Familial characteristics, India

Paper type Research paper

\section{Introduction}

Family as an important buying and consuming unit has been well established in the literature whereby a wide variety of goods and services are bought and consumed almost on a daily basis. Hence, the aspects concerning these decisions such as the character, influence, depth of intra-familial interactions and family members' characteristics constitute a significant dimension of family buying decisions and a well-researched topic in the field of consumer behavior, a segment of marketing. Children, being an integral part of a family, have also been documented to play an important role in these decisions (Ghouse et al., 2020; Rao, 2020; NRF, 2019; Chaudhary et al., 2018); however, the majority of the existing studies have focused mainly on (1) the results of family buying decisions, (2) uni-dimensional in approach by considering only urban children and (3) children in developed western countries. Beyond doubt, the results proposed by such studies are extremely useful as they provide an essential theoretical background for further interrogation of them in countries other than developed countries like India where the family consumption pattern and consequently the family decision-making too is going through a metamorphosis change, such as witnessing an increased level of children's participation in family decision-making (Rao, 2020; Pratap, 2019; Chaudhary et al., 2018). Under the new sittings, a new generation of sophisticated young consumers is emerging, which is resourceful, prodigious (50\% of 1.22 billion population is young), watch more than 100 TV channels, buys online, techno-savvy, assertive, well informed, influenced by influencers/bloggers on Instagram, YouTube, Snapchat, etc., has taste toward modern western culture and has an impact on India's development and its positioning in the world (Joshi, 2019; Mittal et al., 2020; Mohanram, 2012).

More specifically, in the Indian context, the execution of this study during the ongoing Covid-19 pandemic seemed significant mainly for five reasons: firstly, the mammoth Indian population of 1392 million people (Worldometers, 2021); secondly, ranking of India as the sixth biggest economy and projected by Centre for Economics and Business Research (2021) to become world's third largest economy by 2030, overtaking the UK in 2025, Germany in 2027 and Japan in 2030; thirdly, India is a culturally distinct country where despite many cultures, languages, religions, gender norms, family size, structures and traditions, people live in love, affection, peace and harmony, resulting in different consumption choices as compared to other countries; fourthly, about $50 \%$ of Indian population is young, e.g. median age being 28.4 years (Worldometes, 2021); and finally, very few existing studies conducted in India are extremely restricted in scope and partially examined children's role in family buying decisions by taking urban children that too only for child-centric products. Commensurate with this backdrop, this study is being undertaken with the under mentioned objectives:

(1) To examine parental perception about their children's influence in family purchase decisions;

(2) To assess the influence exerted by children across four decision-making stages (DMS) for child-product and family-product;

(3) To ascertain the impact of familial characteristics (size and structure) on the influence exerted by children's influence in family purchase decisions; and

(4) To drive practical and social implications based on analyses results.

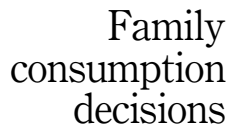


SAJM

2,2

The rest of the paper is organized as follows: the next section represents the review of literature and justifies the importance of the study, Section 3 narrates the process methodology opted to conduct this research, Section 4 explains the results, and finally, the paper is concluded by drawing conclusions and implications.

\section{Literature review}

Literature has recognized that children exert a considerable amount of influence in family buying decisions for a wide array of products, and this influence is increasing over time (Ghouse et al., 2020). Acknowledging their influence, in recent years, there has been a steady increase in the attention paid to children as a distinguished market segment by policymakers, researchers and marketers (Chaudhary et al., 2018). The increasing attention on children's role is largely because of children's increasing influence in family buying decisions. As compared to earlier times, now the relations between parents and children are also becoming more open, friendly, democratic and participative, thereby upgrading children's power in families across countries and cultures (Rao, 2020; Ali et al., 2013).

Children's participation in family buying decisions is often supported by parents wanting to spend quality time with their children (Pratap, 2019; Gram, 2007). Many parents are also becoming "curling parents," who do everything to please their children and make their childhood as smooth as possible; accordingly, they let their children decide in most cases. Some of the possible reasons accountable for this may be the excessive importance attached to the academic performance of children in the society, increase in the number of working mothers, decreasing number of children per family, better nutrition, better facilities, the greater role of media, over-indulgence by parents and nuclear families (Bisht, 2008).

\subsection{Children as influencers}

Past research also reports children's influence in family buying decisions to vary across stages of the decision-making process and the type of product involved (Ghouse et al., 2020; Martensen and Gronholdt, 2008). Children, in most of the past studies, have been documented to exert the maximum influence at the first stage, i.e. the purchase initiation stage (Chaudhary, 2015; Belch et al., 1985), and minimum at the final stage, i.e. the choice stage (Wang et al., 2004). Research also shows that the relevance and perceived importance of the product to the child, and the influence exerted by him/her in the purchase of such product, are positively correlated. Thus, in a child-centered Indian culture, it is pertinent to assume that children dramatically affect family expenditures leading to hypothesize that:

H1. Parents perceive their children to exert influence in family buying decisions.

$H 2 a-b$. Children's influence in family buying decisions varies across stages of the decision-making process (H2a) and type of product (H2b).

\subsection{Children as influencers: moderating factors}

2.2.1 Family size. Previous studies conceded the effect of family size (in terms of the number of siblings) on the influence exerted by children in family buying decisions. Some studies have found children's influence to increase in large families (Dibaba and Mitike, 2016; Ali et al., 2013; Jenkins, 1979), while others have found that children in large families perceived significantly less influence than children in small families (Page et al., 2017; Guneri et al., 2009), and some of the studies have found that the size of the family does not affect children's influence attempts (Akinyele, 2010). Smaller families when compared with large families can provide better education and more material wealth to their children and hence, more opportunities for a child to actively participate in family buying decisions, which may be 
easier if he/she is not competing with other children in the family (Johnson et al., 1994). For further investigation of these results in the Indian context, it is proposed that:

$H 3 a$. Children's influence in family buying decisions across stages of the decisionmaking process for child-product and family-product varies across the family size.

Existing literature has validated that the variable "family structure" moderates children's influencing behavior in family buying decisions. The majority of the past studies in this field assume that the children are growing up in two-parent family structures, i.e. nuclear family structures. Few studies have also explored the influencing behavior of children in single-parent families and found children to exert higher influence in single-parent families than those from two-parent families (Anderson et al., 1989). Contrary to this, some researchers have also found that teenagers from single-parent families are not more likely to be more influential than their counterparts in two-parent families (Dibaba and Mitike, 2016; Chaudhary, 2015; Lachance et al., 2000). India is a country known for its cultural diversity. The joint family system where parents live together with their children and other close relatives has existed in India for decades now and is perhaps unique to this country, or at least its popularity. However, this way of living is fast depleting with the spread of western values, higher media exposure, increased women participation in the workforce and urbanization, consequently a new form of family structurethe nuclear family structure is fast emerging (Chaudhary and Gupta, 2012).

The structural differences between the joint family and nuclear family (comprising of a married couple (husband and wife) and their unmarried children) may lead to different interaction patterns among members of the two family types. Compared to children in joint families, children in nuclear families are encouraged to work individually, to take the initiative and to work independently at an early age (Dinisman et al., 2017; Prakash, 2015). Hence, it is assumed that:

H3b. Children's influence in family buying decisions across stages of the decisionmaking process for child-product and family-product varies across the family structure.

\subsection{Children as influence: theoretical perspective}

The focus of past studies has been on the externalities of the family consumption decisions instead of the internalities of the family consumption process leading to an inadequate investigation into the theoretical explanations for these variances. One useful approach in this direction can be the relative theory approach that talks about the various tangible and intangible resources possessed and used by individuals, including children, in a family setup to influence each other, and the family consumption decisions.

The resource theory, originally propagated by Edna and Uriel Foa in the year 1971 (Foa et al., 1993), is a theory of social exchange or a social psychological framework to understand the relationship between individuals' resources and social interactions that leads to the development of relationships between them at micro and macro level regularly. These social interactions can be direct or reciprocal (Foa et al., 1993) and are based on some resources, which govern such interactions. Blood and Wolfe (1960) have defined resources as anything that one person may make available to others to satisfy his/her as well as their needs or goals. According to this theory, these resources include both tangible resources, such as money and property, and intangible resources, such as age, love, affection, information, knowledge, education, occupation, experience, training and status (Dallos and Dallos, 1997). This theory postulates that humans are social beings and hence cannot satisfy all of their needs in isolation. Social interactions and interrelationships provide the necessary means by which individuals exchange the required resources with each other to satisfy their physical and psychological needs.

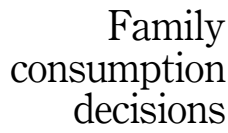

133 
SAJM

2,2

This theory is frequently used to investigate the patterns responsible for specific human interactions and exchanges that take place in their public and private domains daily. At the micro level, researchers have applied this theory to understand the usage of power of various sources in family buying decisions (Flurry, 2007) and found that within a family, the possession of powerful resources will determine the extent of influence exerted by an individual (husband/wife/children/others) in family consumption decisions (Flurry, 2007; Tashakkori and Teddlie, 2003; Blood and Wolfe, 1960). Few of the researchers have also extended the preview of this theory to examine the changing roles and importance of children in family consumption-related decisions (Flurry, 2007). Mcdonald (1980) has proposed that an individual within the family may derive power from five types of resources such as normative (familial values and norms), economic (monetary control exerted by the income earner), affective (love, affection, interpersonal relationships), personal (physical appearance and role competence) and cognitive resources (mental capabilities and intelligence). Depending upon the situation, different resources individually or collectively may be used by the family member(s) to influence a particular buying decision, e.g. husband or wife may frequently make use of normative and economic resources (Beatty and Talpade, 1994; Ekstrom et al., 1987; Moschis and Churchill, 1979), whereas the children may use affective and cognitive resources most frequently in family buying-related interactions.

The resource theory also explains the positive correlation between children's quantum of resources and the influence exerted by them in purchase decisions (Wang et al., 2007). Children's resources may lead to reversal of influence in family (Sheth and Mittal, 2004) when a child is exposed to new knowledge or technology that decreases a child's dependence on his/ her parents; consequently, in situations where the preferences of children are different from their parents, they exercise significant influence. Resources of children, which have been examined in the literature, include income contribution, employment status, education, school grades, parental love and affection, birth order and knowledge about the marketplace and to use technically complicated products (Flurry, 2007).

\section{Research methodology}

The major input contribution to this study is the primary data obtained from a sample of 180 mothers of adolescent children of the age group 13-18 years of age and the corresponding classes being 8th to 12th from urban and rural areas of Delhi, India. The convenience sampling procedure was used for the selection of surveyed respondents because of its easy approachability, willingness of to participate in this study and collection of data in the shortest possible time. Further, mothers of school-going children constituted the target population for several reasons: (1) most previous studies have found children to overestimate the influence exerted by them in family buying decisions (Belch et al., 1985); (2) mothers are often the recipients of greater influence attempts of children (Cowan and Avants, 1988); and (3) in general, mothers are considered as the main buying agent for the family (Darley and $\mathrm{Lim}, 1986)$. However, this sample can also be considered as a random sample as it was entirely voluntary for mothers having a child in class 8th to 12th to be part of this survey (Charles, 2015).

Web-based survey, designed on the Google Forms, was used for data collection due to the ongoing Covid-19 pandemic whereby strict restrictions were imposed on physical movements across the country to mitigate the impact of this pandemic; hence, it seemed to be the most relevant, convenient and widely used way to approach the respondents during this time (Davis et al., 2021; Rehman and Arif, 2021). The prospective respondents were approached electronically via email, WhatsApp groups, Instagram and Facebook. The data collection period lasted for three months, i.e. from January to March 2021.

The survey procedure started with the identification of one of the children by surveyed mothers with the underlying condition that the chosen child must be studying in class 8th to 
12 th at the time of the survey. Thereafter, mothers were asked to provide the needed input for this study in respect of the child chosen by them. The underlined procedure resulted in the average age of the children as referred to by the surveyed mothers to be 14.9. The sample consisted of mothers of 97 male $(53.9 \%)$ and 83 female $(46.1 \%)$ children. All the surveyed families had educated parents, e.g. about $30 \%$ of mothers and $25 \%$ of fathers were graduates and above, and the majority of families $(82.3 \%)$ had only single earning parent (mother/ father). According to the size of the family, the sample consisted of $43.9 \%$ small families (having one or two children), and 56.1\% large families (having three or more than three children). Structure-wise, the surveyed families were divided into nuclear families (parents living with their unmarried children) and joint families (parents and their unmarried children living together with grandparents, uncles, aunts, etc.). Accordingly, the surveyed sample consisted of 114 joint families $(63.3 \%)$ families and 66 nuclear families $(36.7 \%)$. The demographic profile of the surveyed sample is given in Table 1.

\subsection{Research instrument}

A structured non-disguised pre-tested questionnaire was adopted for data collection. The questionnaire was divided into three sections and contained questions in chronological order. Section 1 covered demographic data in terms of children characteristics (age and gender), parental characteristics (education and working status) and familial characteristics (size and structure). Sections 2 and 3 of the questionnaire contained questions on the influence exerted by children in family buying decisions for child product and family product, respectively. For the ease of understanding of the respondents, two versions of the questionnaire, one in English and the other in Hindi (regional language), were developed by using a backtranslation approach to ensure consistency of both versions. Respondents were given a choice to complete the questionnaire in the language that they felt most comfortable with. Each version of the questionnaire required 20-25 min to complete. Pre-testing of the questionnaire was done based on a sample consisting of 18 respondents, resulting in few modifications. Finally, the questionnaire was administered online personally, and any

\begin{tabular}{|c|c|c|c|}
\hline Characteristic & & Number $(N=180)$ & Percent $(\%)$ \\
\hline \multirow[t]{3}{*}{ Children's age (years) } & $13-14$ & 75 & 41.7 \\
\hline & $15-16$ & 82 & 45.6 \\
\hline & $17-18$ & 23 & 23.0 \\
\hline \multirow[t]{2}{*}{ Children's gender } & Male & 97 & 53.9 \\
\hline & Female & 83 & 46.1 \\
\hline \multirow[t]{4}{*}{ Mothers' education } & Illiterate & - & - \\
\hline & Class 1-8 & 37 & 20.6 \\
\hline & Class 9-12 & 89 & 49.4 \\
\hline & Graduation and above & 54 & 30.0 \\
\hline \multirow[t]{4}{*}{ Fathers' education } & Illiterate & - & - \\
\hline & Class $1-8$ & 25 & 13.9 \\
\hline & Class 9-12 & 110 & 61.1 \\
\hline & Graduation and above & 45 & 25.0 \\
\hline \multirow[t]{2}{*}{ Parents' working status } & Both parents working & 32 & 17.8 \\
\hline & Single parent working & 148 & 82.3 \\
\hline \multirow[t]{2}{*}{ Family size } & Small family & 79 & 43.9 \\
\hline & Large family & 101 & 56.1 \\
\hline \multirow[t]{2}{*}{ Family structure } & Nuclear family & 66 & 36.7 \\
\hline & Joint family & 114 & 63.3 \\
\hline
\end{tabular}

Source(s): Online survey

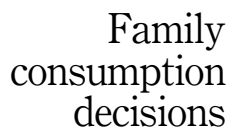

135 
SAJM

2,2

clarifications sought were attended simultaneously (telephonically), which ensured a 100\% response rate. Confidentiality of responses was assured to the survey participants, and informed consent of the respondents was obtained in the beginning of the survey.

\subsection{Product selection}

Two separate lists of products were provided to the respondents at the beginning of the survey. Respondents (mothers) were asked to identify one product from each category and provide their inputs about the influence exerted by their child (chosen in the beginning of the survey by them for this study) in the purchase of these products. The first list included the products (play station, mobile phone, computer and cycle) that may have been purchased in the family mainly for child's personal use (hereafter known as "child-product"), while the second list contained the products (car, television, furniture, refrigerator and two-wheeler) that may have been purchased in the family mainly for the whole family consumption (hereafter known as "family-product"). For better and more accurate recall, only those mothers have participated in the survey in whose families at least one product from each of the two lists had been purchased during the past two years.

\subsection{Children as influencers: conceptualization}

Family is a unique buying identity where a majority of the consumption decisions are collective rather than individualistic and hence are influenced by each member's role in the family, by their perceptions, goals, beliefs and values. Buying decisions in a family pass through a sequence of stages by which a family makes choices that guide its consumption behavior. In this study, children's influence is conceptualized as the extent to which he/she has been engaged in each of the four DMS, i.e. purchase initiation stage, information search and evaluation stage, decision-making stage and actual buying stage for the purchase of child-product and family-product. The scale used for this purpose is an 11-item modified version of the scale developed by Talpade and Talpade (1995). Keeping in mind the comprehension level of the respondents, minor modifications were made in the wordings of a few of the scale statements. The adopted scale items are enlisted in Appendix 1 (for childproduct) and Appendix 2 (for family-product). Respondents were asked to rate their child's influence on a five-point scale for each product separately $(1=$ no influence at all to $5=$ very high influence).

\subsection{Tools and techniques for data analysis}

Previous studies in the field have guided the usage of select analyses tools and techniques. Accordingly, descriptive statistics (mean and standard deviation) were computed across the stages of the family decision-making process to ascertain the variations in the influence exerted by children for child-product and family-product. To examine the statistical significance of variations reported by descriptive statistics, mean differences, ANOVA tests were applied. Also, to see as to which pairs of mean influence scores are significantly different, pairwise comparisons were performed in respect of children's influence in DMS across family size and family structure for both the products using Bonferroni adjustments.

\section{Findings and discussion}

To assess the reliability of the scale items, Cronbach alpha values were computed for all the scale items, and the corresponding results are summarized in Table 2 . The scales adequately met the standards for the present research as all the values of the coefficient of Cronbach alpha are greater than the desired threshold of 0.60, as suggested by Nunnally (1967). 
To validate H1, i.e. parents perceive their children to exert influence in family buying decisions for child-product and family-product, the mean scores of children's influence across four DMS for both the child-product and family-product were computed and are presented in Table 3. Contrary to the expectations, a comparison of the mean scores, moreover, reveals that as compared to child-product children have exerted more influence in case of family-product across all the DMS: purchase initiation stage $\left(M_{\text {child-product }}=3.18\right.$, $\left.M_{\text {family-product }}=3.42\right)$, information search and evaluation stage $\left(M_{\text {child-product }}=2.95\right.$, $\left.M_{\text {family-product }}=3.16\right)$, decision-making stage $\left(M_{\text {child-product }}=2.64, M_{\text {family-product }}=2.67\right)$ and actual buying stage $\left(M_{\text {child-product }}=2.78, M_{\text {family-product }}=2.92\right)$.

The mean influence scores as enumerated in Table 3 are different (range 3.42-2.64), and well above the mid-value (i.e. 2.5 on a scale of $1-5$ ), indicating that parents perceive their children to exert influence in family buying decisions across both the products. The analysis results, thus, lead to the acceptance of $\mathrm{H} 1$. These results are similar to the results of past studies (Ghouse et al., 2020; Chaudhary, et al., 2018; Darley and Lim, 1986; Belch et al., 1985).

H2a-b proposed that children's influence in family buying decisions varies across stages of the decision-making process (H2a) and type of product (H2b). The first part of this hypothesis, i.e. H2a, was examined by conducting pairwise comparisons across all the stages of the decision-making process by using Bonferroni adjustments, and the results are summarized in Table 4. Significant differences were observed between all the pairs of the DMS, leading to the acceptance of H2a. This result is parallel to the findings of existing literature whereby children were found to differ in their influence on family buying decisions across stages of the decision-making process (Ghouse et al., 2020; Chaudhary, 2015).

For the assessment of the second part of H2a-b, a one-way between-groups' analysis of variance (ANOVA) was conducted, and the analysis results are presented in Table 5 . The results clearly show that as compared to child-product, the influence exerted by children in case of family-product across all the four stages of the family decision-making process is quite high. The maximum difference in children's influence across the product was observed at the first decision-making stage, i.e. the purchase initiation stage $(F=27.29, p=0.000)$, and

\begin{tabular}{lccc}
\hline Scale items & No. of items & Child-product $(\alpha)$ & Family-product $(\alpha)$ \\
\hline Purchase initiation stage & 3 & 0.71 & 0.76 \\
Information search and evaluation stage & 2 & 0.77 & 0.69 \\
Decision-making stage $_{\text {Actual buying stage }}^{1}$ & 5 & 0.72 & 0.73
\end{tabular}

Source(s): Online survey

Note(s): 1 . Reliability coefficient cannot be computed as the scale consists of only one item

\section{Family consumption decisions}

137
Table 2.

Reliability analyses of decision-making scale

\begin{tabular}{lcccc}
\hline $\begin{array}{l}\text { Decision making stages } \\
\text { (DMS) }\end{array}$ & $\begin{array}{c}\text { Mean (standard } \\
\text { deviation) }\end{array}$ & $\begin{array}{c}\text { Child } \\
\text { Diference from } \\
\text { mid-value }\end{array}$ & $\begin{array}{c}\text { Mean (standard } \\
\text { deviation) }\end{array}$ & $\begin{array}{c}\text { product } \\
\text { Difference from } \\
\text { mid-value }\end{array}$ \\
\hline Stage 1: Purchase initiation & $3.18(0.99)$ & 0.68 & $3.42(1.00)$ & 0.92 \\
Stage 2: Information search & $2.95(1.15)$ & 0.45 & $3.16(1.21)$ & 0.66 \\
and evaluation stage & & & & \\
Stage 3: Decision-making & $2.64(0.89)$ & 0.14 & $2.67(0.88)$ & 0.17 \\
Stage 4: Actual buying & $2.78(1.16)$ & 0.28 & $2.92(1.35)$ & 0.42
\end{tabular}

Source(s): Online survey

Table 3.

Mean scores, standard deviations for children's influence in DMS 
SAJM

2,2
138

Results relating to pairwise comparisons ${ }^{1}$

\begin{tabular}{|c|c|c|c|c|c|c|c|}
\hline \multirow[b]{2}{*}{ Product } & \multirow[b]{2}{*}{$\begin{array}{c}\text { (I) } \\
\text { DMS }^{2,3}\end{array}$} & \multirow[b]{2}{*}{$\begin{array}{c}(\mathrm{J}) \\
\mathrm{DMS}^{2,3}\end{array}$} & \multirow[b]{2}{*}{$\begin{array}{l}\text { Mean difference } \\
(\mathrm{I}-\mathrm{J})^{4,5}\end{array}$} & \multirow[b]{2}{*}{$\begin{array}{l}\text { Std. } \\
\text { error }\end{array}$} & \multirow[b]{2}{*}{ Sig. ${ }^{4}$} & \multicolumn{2}{|c|}{$\begin{array}{l}95 \% \text { confidence interva } \\
\text { for difference }\end{array}$} \\
\hline & & & & & & $\begin{array}{l}\text { Lower } \\
\text { bound }\end{array}$ & $\begin{array}{l}\text { Upper } \\
\text { bound }\end{array}$ \\
\hline \multirow{12}{*}{$\begin{array}{l}\text { Child- } \\
\text { product }\end{array}$} & \multirow[t]{3}{*}{1} & 2 & $0.681 *$ & 0.047 & 0.053 & -0.002 & 0.463 \\
\hline & & 3 & $0.548^{*}$ & 0.084 & 0.000 & 0.324 & 0.772 \\
\hline & & 4 & $0.306^{*}$ & 0.093 & 0.007 & 0.059 & 0.552 \\
\hline & \multirow[t]{3}{*}{2} & 1 & $-0.681 *$ & 0.047 & 0.053 & -0.463 & 0.002 \\
\hline & & 3 & $0.317^{*}$ & 0.079 & 0.001 & 0.107 & 0.528 \\
\hline & & 4 & $0.275 *$ & 0.086 & 0.050 & -0.164 & 0.314 \\
\hline & \multirow[t]{3}{*}{3} & 1 & $-0.548^{*}$ & 0.084 & 0.000 & -0.772 & -0.324 \\
\hline & & 2 & $-0.317^{*}$ & 0.079 & 0.001 & -0.528 & -0.107 \\
\hline & & 4 & $-0.242^{*}$ & 0.075 & 0.009 & -0.444 & -0.041 \\
\hline & \multirow[t]{3}{*}{4} & 1 & $-0.306^{*}$ & 0.093 & 0.007 & -0.552 & -0.059 \\
\hline & & 2 & $-0.275^{*}$ & 0.086 & 0.050 & -0.314 & 0.164 \\
\hline & & 3 & $0.242 *$ & 0.075 & 0.009 & 0.041 & 0.444 \\
\hline \multirow{12}{*}{$\begin{array}{l}\text { Family- } \\
\text { product }\end{array}$} & \multirow[t]{3}{*}{1} & 2 & $0.258^{*}$ & 0.079 & 0.008 & 0.047 & 0.470 \\
\hline & & 3 & $0.754 *$ & 0.065 & 0.000 & 0.580 & 0.929 \\
\hline & & 4 & $0.789 *$ & 0.099 & 0.000 & 0.524 & 1.054 \\
\hline & \multirow[t]{3}{*}{2} & 1 & $-0.258^{*}$ & 0.079 & 0.008 & -0.470 & -0.047 \\
\hline & & 3 & $0.496^{*}$ & 0.063 & 0.000 & 0.328 & 0.664 \\
\hline & & 4 & $0.531 *$ & 0.094 & 0.000 & 0.280 & 0.781 \\
\hline & \multirow[t]{3}{*}{3} & 1 & $-0.754 *$ & 0.065 & 0.000 & -0.929 & -0.580 \\
\hline & & 2 & $-0.496^{*}$ & 0.063 & 0.000 & -0.664 & -0.328 \\
\hline & & 4 & $0.634^{*}$ & 0.045 & 0.009 & -0.180 & 0.249 \\
\hline & \multirow[t]{3}{*}{4} & 1 & $-0.789 *$ & 0.099 & 0.000 & -1.054 & -0.524 \\
\hline & & 2 & $-0.531 *$ & 0.094 & 0.000 & -0.781 & -0.280 \\
\hline & & 3 & $-0.634 *$ & 0.045 & 0.009 & -0.249 & 0.180 \\
\hline
\end{tabular}

Note(s): 1 . Values typed in italic pertain to the significant mean differences

2. DMS: Decision-making stages are: $1=$ Purchase initiation stage, $2=$ Information search and evaluation stage, $3=$ Decision-making stage and $4=$ Actual buying stage

3. Significance level reported after Bonferroni adjustments

4. $p<0.05$

Source(s): Online survey

Table 5.

Children's influence in DMS: ANOVA

\begin{tabular}{lcccc}
\hline & $\begin{array}{c}\text { Child-product } \\
\text { Mean (standard } \\
\text { deviation) }\end{array}$ & $\begin{array}{c}\text { Family-product } \\
\text { Mean (standard } \\
\text { deviation) }\end{array}$ & $\begin{array}{c}\text { Mean } \\
\text { differences }\end{array}$ & $\begin{array}{c}F \text {-ratio } \\
(p \text {-value) }\end{array}$ \\
\hline DMS & $3.18(0.99)$ & $3.42(1.00)$ & -0.24 & $27.29(0.000)^{*}$ \\
Stage 1: Purchase initiation & $2.95(1.15)$ & $3.16(1.21)$ & -0.21 & $21.45(0.000)^{*}$ \\
Stage 2: Information search & & & & \\
and evaluation stage & $2.64(0.89)$ & $2.67(0.88)$ & -0.03 & $10.57(0.000)^{*}$ \\
Stage 3: Decision-making & $2.78(1.16)$ & $2.92(1.35)$ & -0.14 & $18.95(0.000)^{*}$ \\
Stage 4: Actual buying & & & & \\
Note(s): $p<0.05$ & & & & \\
Source(s): Online survey & & & &
\end{tabular}

the least at the decision-making stage $(F=10.57, p=0.000)$. All the differences were found to be statistically significant, leading to the acceptance of $\mathrm{H} 2 \mathrm{~b}$, i.e. children's influence in family buying decisions varies across the type of product. This result is similar to the findings of past studies (Chaudhary et al., 2018; Chaudhary, 2015; Nancarrow et al., 2011). 
The first part of the third hypothesis (H3a) states that children's influence in family buying decisions across the stages of decision-making process for child-product and family-product varies across the family size. For the purpose of analysis, the mean scores of children's influence in small and large families were computed across four DMS separately for both the child-product and the family-product and the respective results are presented in Table 6. The mean influence scores of children are in the range of 3.26-2.59. This indicates that children do exert influence in family decision-making, and this influence is affected by the size of their families.

To ascertain the statistical significance of differences of mean influence scores of children across family sizes, mixed factorial (between-within subjects) repeated-measures ANOVA was applied on data by taking "decision-making stages" and "product type" as within-subject factors and "family size" as between-subject factors. The respective analysis results are reported in Table 7 . The effect of the variable "family size" was found to be insignificant, $F(1,178)=0.004, p=0.951$. This implies that family size does not significantly affect the influence exerted by children in family buying decisions, thus leading to the rejection of H3a. This result is in line with the result of past studies (Ali et al., 2013; Chaudhary and Gupta, 2012; Akinyele, 2010) whereby children are found to be influential irrespective of the size of their families.

Further, to make the analysis more comprehensive, pairwise comparisons by using Bonferroni adjustments were undertaken in respect of children's mean influence scores in DMS across small and large families for both the products. The purpose behind this was to obtain the information as to which pairs of mean scores are significantly different. The results are summarized in Table 8. As expected, the variable "family size" has no significant impact on the influence exerted by children at any of the DMS across child product and family product; however, the differences of mean influence scores of children in small families and large families are positive in the majority ( 6 out of 8 ) of the cases, thus indicating that children in small families, in general, exert higher influence than the children in large families.

The second part of the third hypothesis (H3b) proposed that the children's influence in family buying decisions across stages of the decision-making process for child-product and family-product varies across the family structure. To ascertain the validity of this proposition, first, the mean scores of children's influence in nuclear and joint families were computed across four DMS for both the child-product and family-product. The results are presented in Table 9. Children's mean influence scores are varying in the range of 3.45 to 2.53, thus indicating that children do exert influence in family buying decisions and this influence is affected by the structure of their families.

The statistical significance of differences of mean influence scores of children across family structures was ascertained by using the mixed factorial (between-within subjects) repeated-measures ANOVA was applied on data by taking "decision-making stages" (4 levels) and "product type" (2 levels) as within-subject factors and "family structure" (2 levels) as between-subject. The between-within subjects' effects on the variable "family structure" are reported in Table 10. The main effects are found to be significant, $F(1,178)=2.068$, $p=0.049$, indicating that the variable "family structure" does affect the influence exerted by children in family buying decisions. The results, thus, provide support for the acceptance of H3b. These results are in line with previous studies (Dinisman et al., 2017; Tinson et al., 2008), which have found the impact of families' structures on the influence exerted by children in family decisions to be significant.

Pairwise comparisons were conducted using Bonferroni adjustments to see which pairs of mean scores are significantly different in respect of children's influence in the DMS across joint and nuclear families for both the products. The results are summarized in Table 11. As expected, the variable "family structure" has a significant impact on the influence exerted by children at all the DMS, except the actual buying stage in the case of child-product as well as

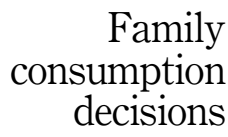

139 
SAJM

2,2

140

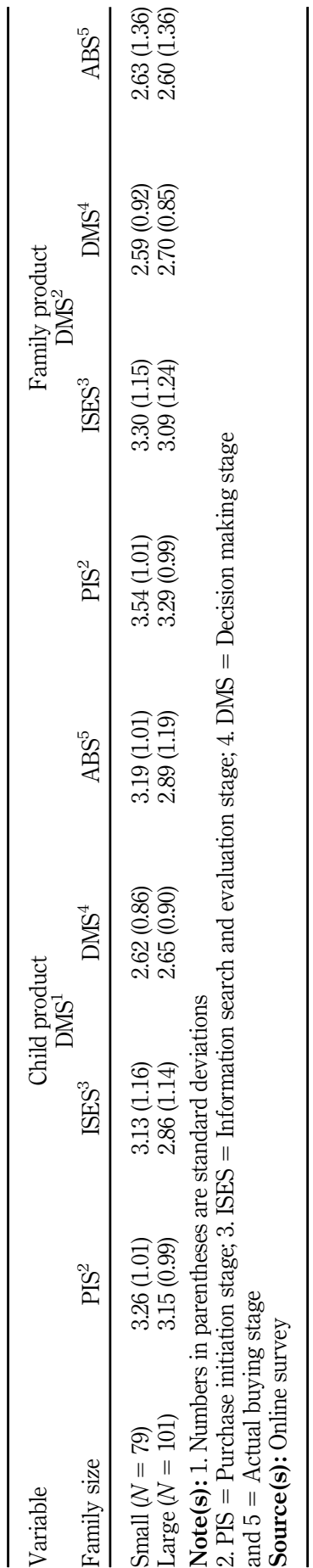

Table 6.

Mean scores of

children's influence in

DMS in Indian families:

family size-wise 
family-product. The differences in mean influence scores are positive in all the cases, thus indicating that children in nuclear families in general, exert higher influence in family buying decisions than the children in joint families. These results, thus, provide further support for the acceptance of $\mathrm{H} 3 \mathrm{~b}$.

\section{Conclusion and implications}

This study confirms previous research results pertaining to the examination of the role of children in family buying decisions in accordance with the theoretical foundations laid by the resource theory. Notable findings that emerged from this study revealed that parents in Indian families (1) perceive their children to exert influence in family buying decisions, (2) children's influence varies across stages of the decision-making process and the type of product, and (3) children's influence in family buying decisions is moderated by their family structure but not by family size. The findings of this study provide important managerial implications leading to the enrichment of theoretical knowledge in the field of family buying behavior in India and by extension in other similar countries.

\subsection{Practical implications}

The results of this study support the notion that children exert considerable influence in family buying decisions in India across products, hence constitute a viable target market for

\begin{tabular}{lcccccc}
\hline Source & Sum of squares & df1 & df2 & Mean square & $F$-ratio & Sig \\
\hline Family size & 0.017 & 1 & 178 & 0.017 & 0.004 & 0.951
\end{tabular}

Note(s): $p<0.05$

Source(s): Online survey

\section{Family consumption decisions}

\begin{tabular}{|c|c|c|c|c|c|c|c|c|}
\hline \multirow[b]{2}{*}{ Products } & \multirow[b]{2}{*}{$\mathrm{DMS}^{2}$} & \multirow[b]{2}{*}{$\begin{array}{l}\text { (I) family } \\
\text { size }\end{array}$} & \multirow[b]{2}{*}{$\begin{array}{l}\text { (J) family } \\
\text { size }\end{array}$} & \multirow{2}{*}{$\begin{array}{c}\text { Mean } \\
\text { difference } \\
(\mathrm{I}-\mathrm{J})^{2}\end{array}$} & \multirow[b]{2}{*}{$\begin{array}{l}\text { Std. } \\
\text { error }\end{array}$} & \multirow[b]{2}{*}{ Sig. ${ }^{3}$} & \multicolumn{2}{|c|}{$\begin{array}{l}95 \% \text { confidence } \\
\text { interval for difference }\end{array}$} \\
\hline & & & & & & & $\begin{array}{l}\text { Lower } \\
\text { bound }\end{array}$ & $\begin{array}{l}\text { Upper } \\
\text { bound }\end{array}$ \\
\hline \multirow[t]{4}{*}{$\begin{array}{l}\text { Child-- } \\
\text { product }\end{array}$} & 1 & $\begin{array}{l}\text { Small } \\
\text { family }\end{array}$ & $\begin{array}{l}\text { Large } \\
\text { family }\end{array}$ & 0.110 & 0.157 & 0.483 & 0.200 & 0.421 \\
\hline & 2 & $\begin{array}{l}\text { Small } \\
\text { family }\end{array}$ & $\begin{array}{l}\text { Large } \\
\text { family }\end{array}$ & 0.269 & 0.181 & 0.139 & 0.088 & 0.626 \\
\hline & 3 & $\begin{array}{l}\text { Small } \\
\text { family }\end{array}$ & $\begin{array}{l}\text { Large } \\
\text { family }\end{array}$ & -0.025 & 0.140 & 0.860 & -0.300 & 0.251 \\
\hline & 4 & $\begin{array}{l}\text { Small } \\
\text { family }\end{array}$ & $\begin{array}{l}\text { Large } \\
\text { family }\end{array}$ & 0.039 & 0.184 & 0.832 & 0.402 & 0.324 \\
\hline \multirow[t]{4}{*}{$\begin{array}{l}\text { Family- } \\
\text { product }\end{array}$} & 1 & $\begin{array}{l}\text { Small } \\
\text { family }\end{array}$ & $\begin{array}{l}\text { Large } \\
\text { family }\end{array}$ & 0.354 & 0.156 & 0.025 & 0.663 & -0.045 \\
\hline & 2 & $\begin{array}{l}\text { Small } \\
\text { family }\end{array}$ & $\begin{array}{l}\text { Large } \\
\text { family }\end{array}$ & 0.210 & 0.191 & 0.272 & 0.166 & 0.587 \\
\hline & 3 & $\begin{array}{l}\text { Small } \\
\text { family }\end{array}$ & $\begin{array}{l}\text { Large } \\
\text { family }\end{array}$ & -0.111 & 0.138 & 0.424 & -0.383 & 0.162 \\
\hline & 4 & $\begin{array}{l}\text { Small } \\
\text { family }\end{array}$ & $\begin{array}{l}\text { Large } \\
\text { family }\end{array}$ & 0.004 & 0.214 & 0.986 & 0.426 & 0.418 \\
\hline
\end{tabular}

Note(s): 1. Significance level reported after Bonferroni adjustments

2. DMS: Decision-making stages (purchase initiation, information search and evaluation, decision-making and actual buying)

3. $p<0.05$

Table 8.

Results relating to pairwise comparisons ${ }^{1}$ 
SAJM

2,2

142

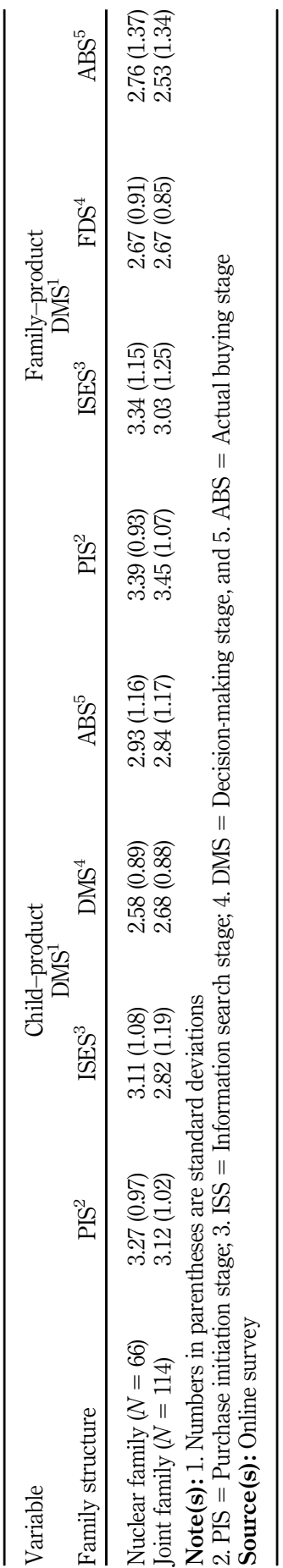

Table 9.

Mean scores of

children's influence in

DMS in Indian families:

family structure-wise

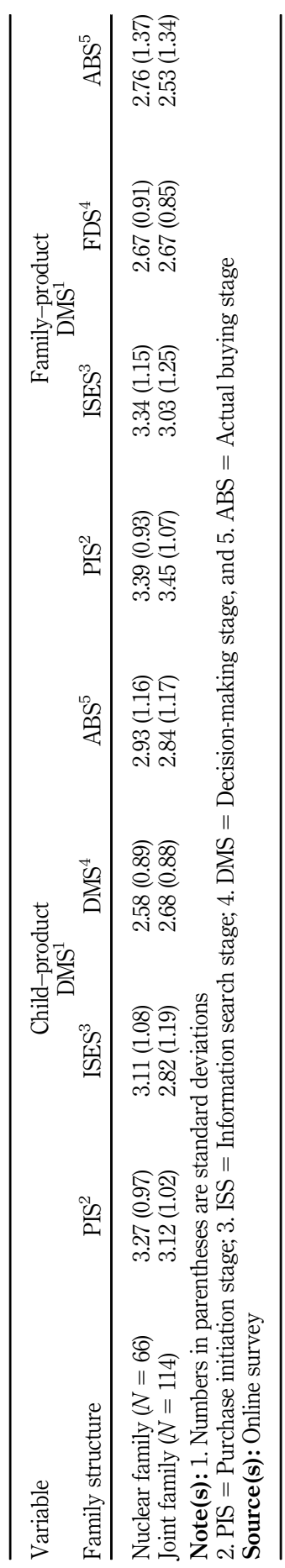


SAJM

2,2 and reliable information providers in families; marketers should make the right use of technology to carve out an effective way of reaching and communicating with them.

\subsection{Social implications}

The finding that although Indian children are actively participating across various stages of the decision-making process and their influence is strongest at the purchase initiation stage has peculiar social implications whereby families may be exposed toward eco-friendly green products and sustainable ways of living through the children in rural as well as urban areas. Similarly, children were also found to be influential at the information search and evaluation stage; hence, the messages regarding social issues, gender equality and health issues, which are not yet openly discussed in Indian families, may be imparted through children for better coverage and effectiveness.

\section{Limitations and suggestions for future research}

Although this study validates the findings of past literature and provides a rich understanding of the issues relating to the influencing role of children in Indian families, still corroborative replications and extensions of this study are needed. This research makes use of convenience and region-specific (Delhi) sample, which may pose restrictions in the generalizability of the results obtained in this study. Hence, to generate findings in this area with wider generalizability, future research should make use of random samples of larger sizes of the population from other states as well. This study may also be replicated in other countries having both similarities and differences with India in terms of cultural background, religious beliefs and pattern of economic development.

\section{References}

Akinyele, S. (2010), "The influence of children on family purchasing decisions in OTA, Nigera", The Journal of Contemporary Management Research, Vol. 4 No. 2, pp. 1-11.

Ali, A., Ravichandran, N. and Batra, D.K. (2013), “Children's choice of influence strategies in family purchase decisions and the impact of demographics", Vision: The Journal of Business Perspective, Vol. 17 No. 1, pp. 27-40.

Anderson, E.R., Hetherington, E.M. and Clingempeel, W.G. (1989), "Transformations in family relations at puberty: effects of family context", Journal of Early Adolescence, Vol. 9 No. 3, pp. 310-334.

Beatty, S.E. and Talpade, S. (1994), "Adolescent influence in family decision making: a replication with extension”, Journal of Consumer Research, Vol. 21 No. 2, pp. 332-341.

Belch, G.E., Belch, M.A. and Ceresino, G. (1985), "Parental and teenage child influences in family decision making", Journal of Business Research, Vol. 13 No. 2, pp. 163-176.

Bisht, S. (2008), Notions of Child and Childhood in India: A Study on Teachers' Perspective, Unpublished M.Phil Dissertation, Jawaharlal Nehru University, Delhi.

Blood, R.P. and Wolfe, D.M. (1960), Husband and Wives: The Dynamics of Married Living, Free Press, Illinois.

Centre for Economics and Business Research (CEBR) (2021), World Economic League Table 2021, 12th ed., available at: https://www.jagranjosh.com/general-knowledge/centre-for-economics-andbusiness-research-cebr-report-india-ranking-1609320206-1 (assessed 4 September 2021).

Charles, K. (2015), "Innovative methodologies for 21st century learning, teaching and assessment: a convenience sampling investigation into the use of social media technologies in higher education", International Journal of Higher Education, Vol. 4 No. 2, pp. 1-26. 
Chaudhary, M. (2015), "Structural equation modelling of child's role in family buying", International Journal of Business Innovation and Research, Vol. 9 No. 5, pp. 568-582.

Chaudhary, M. and Gupta, A. (2012), "Use of influence tactics by children in India", Jindal Journal of Business Research, Vol. 1 No. 1, pp. 115-125.

Chaudhary, M., Ghouse, S.M. and Durrah, O. (2018), "Young Arab consumers: an analysis of family buying process in Oman", Young Consumers, Vol. 19 No. 1, pp. 1-18.

Cowan, G. and Avants, S.K. (1988), "Children's influence strategies: structure, sex differences, and bilateral mother-child influence", Child Development, Vol. 59 No. 5, pp. 1303-1313.

Dallos, S. and Dallos, D. (1997), Couples, Sex and Power, Open University Press, Buckingham.

Darley, W.K. and Lim, J.S. (1986), "Family decision making in leisure-time activities: an exploratory investigation of the impact of locus of control, child age influence factor and parental type on perceived child influence", Advances in Consumer Research, Vol. 13 No. 1, pp. 370-374.

Davis, F., Francis Gnanasekar, M.B. and Parayitam, S. (2021), "Trust and product as moderators in online shopping behavior: evidence from India”, South Asian Journal of Marketing, Vol. 2 No. 1, pp. 28-50, doi: 10.1108/SAJM-02-2021-0017.

Dibaba, B. and Mitike, G. (2016), "Factors influencing desired family size among residents of Assela Town”, Journal of Women's Health Care, Vol. 5 No. 6, doi: 10.4172/2167-0420.1000342.

Dinisman, T., Andresen, S., Montserrat, C., Strózik, D. and Strózik, T. (2017), "Family structure and family relationship from the child well-being perspective: findings from comparative analysis", Children and Youth Services Review, Vol. 80, pp. 105-115, doi: 10.4172/2167-0420.1000342.

Ekstrom, K.M., Tansuhaj, P.S. and Foxman, E.R. (1987), “Children's influence in family decisions and consumer socialization: a reciprocal view", in Wallendorf, M. and Anderson, P. (Eds), NA Advances in Consumer Research, Association for Consumer Research, Provo, UT, Vol. 14, pp. 283-287.

Flurry, L.A. (2007), “Children's influence in family decision making: examining the impact of the changing American family", Journal of Business Research, Vol. 60 No. 4, pp. 322-330.

Foa, U.G., Converse, J. Jr, Törnblom, K.Y. and Foa, E.B. (1993), Resource Theory: Explorations and Applications, Academic Press, Washington.

Ghouse, S.M., Chaudhary, M. and Durrah, O. (2020), “Arab's children's influence on the buying process: comparing parent and child perceptions", Journal of Islamic Marketing, ahead-of-print. doi: 10.1108/JIMA-08-2019-0160 (accessed 18 February 2021).

Gram, M. (2007), "Children as co-decision makers in the family? the case of family holidays", Young Consumers: Insight and Ideas for Responsible Marketers, Vol. 8 No. 1, pp. 19-28.

Guneri, B., Yurt, O., Kaplan, M.D. and Delen, M. (2009), "The influence of children on family purchasing decisions in Turkey", Asian Journal of Marketing, Vol. 2 No. 1, pp. 20-32.

Jenkins, R.L. (1979), "The influence of children in family decision-making: parents' perceptions", Advances in Consumer Research, Vol. 6 No. 1, pp. 413-418.

Johnson, M., McPhail, J. and Yau, O.H.M. (1994), "Conflict in family decision making: a proposal for an investigation of the factors influencing the choice of conflict resolution strategies by children", Asia Pacific Advances in Consumer Research, Vol. 1 No. 1, pp. 229-236.

Joshi, S.V., Stubbe, D., Su-Ting, T.L. and Hilty, D.M. (2019), "The use of technology by youth: implications for psychiatric educators”, Academic Psychiatry, Vol. 43, pp. 101-109, doi: 10.1007/ s40596-018-1007-2 (accessed 16 February 2021).

Lachance, M.J., Frederic, L. and Nerec, B. (2000), "Family structure, parent child communication and adolescent participation in family and consumer tasks and decisions", Family Consumer Sciences Research Journal, Vol. 29 No. 2, pp. 125-152.

Martensen, A. and Gronholdt, L. (2008), "Children's influence on family decision making”, Innovative Marketing, Vol. 4 No. 4, pp. 14-22.

Family
consumption

decisions 
SAJM

2,2

Mcdonald, G.W. (1980), "Family power: the assessment of a decade of theory and research 1970-1979", Journal of Marriage and the Family, Vol. 42 No. 4, pp. 841-854.

Mittal, M., Chaudhary, M. and Garg, S. (2020), "An evaluative framework for the most suitable theory of mobile learning”, Journal of Marketing and Retail Management, Vol. 1 No. 1, pp. 141-155.

Mohanram, A.S. (2012), "How Indian teenagers influence their parents to purchase a computer - an empirical analysis", International Journal of Business Economics and Management Research, Vol. 2 No. 5, pp. 98-116.

Moschis, G.P. and Churchill, G.A. (1979), “An analysis of the young consumer”, Journal of Marketing, Vol. 43 No. 3, pp. 40-48.

Nancarrow, C., Tinson, J. and Brace, I. (2011), "Profiling key purchase influencers: those perceived as consumer savvy", Journal of Consumer Behaviour, Vol. 10 No. 2, pp. 102-110.

NRF (2019), "Keeping up with gen Z", Fall 2019 Consumer View, available at: file://C:/Users/Dell/ Documents/NRF Consumer View Fall 2019.pdf (accessed 18 February 2021).

Nunnally, J.C. (1967), Psychometric Theory, 1st ed., McGraw-Hill, New York.

Page, B., Sharp, A. and Lockshin, L. (2017), "Parents and children in supermarkets: incidence and influence", Journal of Retailing and Consumer Services, available at: https://www.researchgate. net/publication/319328464.

Prakash (2015), "Nuclear and joint families in India", available at: www.importantindia.com /21237/ nuclear-family-vs-joint-family/Retrieved on 2019-08-20.

Pratap, A. (2019), "What role does family play in consumer behavior?", available at: https://notesmatic. com/2019/7/what-role-does-family-play-in-consumer-behavior/ (accessed 16 February 2021).

Rahman, K.T. and Arif, M.Z.U. (2021), "Impacts of binge-watching on Netflix during the COVID-19 pandemic", South Asian Journal of Marketing, Vol. 2 No. 1, pp. 97-112, doi: 10.1108/SAJM-052021-0070.

Rao, P.S. (2020), "No kidding. Children do influence what families are buying", The Hindu Business Line, available at: https://www.thehindubusinessline.com/catalyst/no-kidding-children-doinfluence-what-families-are-buying/ (accessed 18 February 2021).

Sheth, J.N. and Mittal, B. (2004), Customer Behavior: A Managerial Perspective, Thomson, SouthWestern.

Talpade, S. and Talpade, M. (1995), "Development of a multi-item scale to measure teenager influence on family purchases: an exploratory study", Journal of Marketing Theory and Practice, Vol. 3 No. 4, pp. 41-45.

Tashakkori, A. and Teddlie, C. (2003), Handbook of Mixed Methods in Social and Behavioural Research, Sage Publications, California.

Tinson, J., Nancarrow, C. and Brace, I. (2008), "Purchase decision making and the increasing significance of family types”, Journal of Consumer Marketing, Vol. 25 No. 1, pp. 45-56.

Wang, K.C., Hsieh, A.T., Yeh, J.C. and Tsai, C.W. (2004), "Who is the decision maker: the parents or the child in group package towns?”, Tourism Management, Vol. 25 No. 2, pp. 183-194.

Wang, S., Holloway, B.B., Beatty, S.E. and Hill, W.W. (2007), "Adolescent influence in family purchase decisions: an update and cross-national extension”, Journal of Business Research, Vol. 60 No. 7, pp. $1117-1124$.

Worldometers (2021), "Indian pollution live", available at: https:/www.worldometers.info/worldpopulation/india-population/\#: :text=India population is equivalent to $17.7 \% 25$ of the total world population (assessed 4 September 2021). 
Appendix 1

\begin{tabular}{ll}
\hline Construct name & Items \\
\hline Purchase initiation stage & $\begin{array}{l}\text { In bringing up the idea that your family should have this product } \\
\text { In getting your family members to realize that the family needs this } \\
\text { product } \\
\text { In getting other family members to start thinking about buying this } \\
\text { product }\end{array}$ \\
$\begin{array}{l}\text { For visiting the websites/stores to look for different brands/models of this } \\
\text { product } \\
\text { In the examination of different brands or models of this product at the } \\
\text { store/shop/websites } \\
\text { Information search and } \\
\text { evaluation stage }\end{array}$ & $\begin{array}{l}\text { In deciding on the brand/model of the product that was finally purchased } \\
\text { In deciding on which store/website to actually buy the product from }\end{array}$ \\
In deciding on the color of the product that was finally purchased \\
In deciding about the amount to be spent on the product \\
In deciding about the timings (when) to purchase the product \\
In actually buying (co-shopping) this product from the store/shop/ \\
website
\end{tabular}

\section{Appendix 2}

\begin{tabular}{ll}
\hline Construct name & Items \\
\hline Purchase initiation stage & $\begin{array}{l}\text { In bringing up the idea that your child should have this product } \\
\text { In getting your family members to realize that the child needs this } \\
\text { product } \\
\text { In getting other family members to start thinking about buying this } \\
\text { product }\end{array}$ \\
$\begin{array}{l}\text { For visiting the websites/stores to look for different brands/models of this } \\
\text { product } \\
\text { In the examination of different brands or models of this product at the } \\
\text { store/shop/websites } \\
\text { Information search and } \\
\text { evaluation stage }\end{array}$ & $\begin{array}{l}\text { In deciding on the brand/model of the product that was finally purchased } \\
\text { In deciding on which store/website to actually buy the product from }\end{array}$ \\
In deciding on the color of the product that was finally purchased \\
In deciding about the amount to be spent on the product \\
In deciding about the timings (when) to purchase the product \\
In actually buying (co-shopping) this product from the store/shop/ \\
website
\end{tabular}

\section{Corresponding author}

Harikishni Nain can be contacted at: harikishni@gmail.com

For instructions on how to order reprints of this article, please visit our website: 